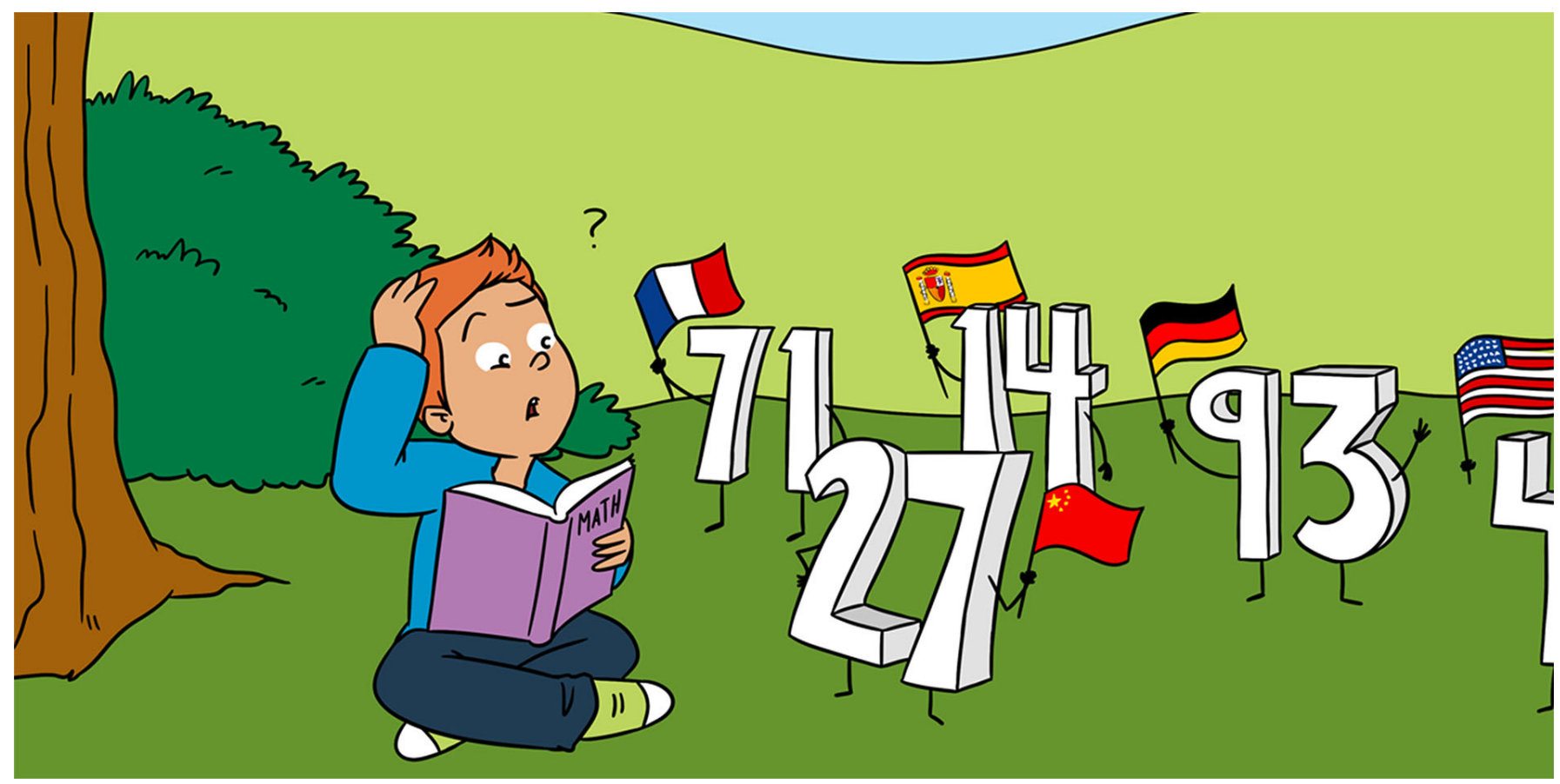

\title{
FORTY-TWO OR TWO-AND-FORTY: LEARNING MATHS IN DIFFERENT LANGUAGES
}

\section{Julia Bahnmueller ${ }^{1,2,3^{*}}$, Hans-Christoph Nuerk ${ }^{2,4}$ and Krzysztof Cipora ${ }^{1,2,4}$ \\ ${ }^{1}$ Centre for Mathematical Cognition, Loughborough University, Loughborough, United Kingdom \\ ${ }^{2}$ LEAD Graduate School \& Research Network, University of Tübingen, Tübingen, Germany \\ ${ }^{3}$ Neuro-Cognitive Plasticity Laboratory, Leibniz-Institut für Wissensmedien, Tübingen, Germany \\ ${ }^{4}$ Department of Psychology, University of Tübingen, Tübingen, Germany}

YOUNG REVIEWERS:

THE

BOMBAY

INTERNATIONAL

SCHOOL

AGES: $13-14$

BRIDGET

AGE: 11

SIENA

AGE: 10
Doing basic maths seems to be a pretty common thing. $2+2$ equals 4, both in France and in China. $7 \times 8$ equals 56, both in the United States of America and in Germany. Although most of us use the same symbols to write down numbers $(1,2,3$, $4, \ldots)$, we use very different words for these numbers simply because we speak different languages. In this article, we will give examples of what number words in different languages look like. We also show how the way multi-digit number words are built can make learning maths and dealing with large numbers easier or more difficult. 
1 Maths is the abbreviation of mathematics used in the United Kingdom In the United States of America, the abbreviation is math.

2 The " $x$ " in $7 \times 8$ is a symbol for multiplication. However, people also use " . " (7 - 8) or "* " $(7 * 8)$ instead.

\section{HINDU-ARABIC} NUMERAL SYSTEM

A set of symbols that is used to write down numbers in most countries. The Hindu-Arabic numeral system uses exactly 10 symbols: 1, 2, 3, 4, 5, 6 ,

$7,8,9$, and 0 . We use these ten symbols to write down single-digit numbers and we combine them when we write down multi-digit numbers.

\section{PLACE-VALUE RULE}

A rule that allows us to write down as many numbers as we want with only the 10 symbols we already know $(1,2,3,4,5,6,7$, $8,9$, and 0$)$. The place-value rule means that the value of each digit becomes clear when we look at the place of this digit within the multi-digit number. For example, the value of the 9 in 92 is 90 ( $9 \times$ 10) and the value of the 2 in 92 is $2(2 \times 1)$. However, in 29 it is the other way around: the value of the 9 is just 9 $(9 \times 1)$ and the value of the 2 is $20(2 \times 10)$. This is why 92 is different from 29, although both are combinations of the same digits!

\section{NUMBERS AND MATHS ARE PRETTY UNIVERSAL}

Doing basic maths ${ }^{1}$ seems to be a pretty common thing-you do it, I do it, even very young children do it before they go to school, for instance, when they count marbles. This is also true for calculations: $2+2$ equals 4 , both in France and in China. $7 \times 8$ equals 56, both in the United States of America and in Germany ${ }^{2}$. Most countries use the so-called Hindu-Arabic numeral system to write down numbers. The Hindu-Arabic numeral system uses exactly ten symbols that you are probably familiar with: $1,2,3,4,5,6,7,8,9$, and 0 . We use these ten symbols to write down single-digit numbers and we combine them when we write down multi-digit numbers.

Multi-digit numbers follow the place-value rule, which allows us to write down as many numbers as we want with only the ten symbols we already know. The place-value rule means that the value of each digit becomes clear when we look at the place of this digit within the multi-digit number. For example, the value of the 9 in 92 is $90(9 \times 10)$ and the value of the 2 in 92 is $2(2 \times 1)$. However, in 29 it is the other way around: the value of the 9 is just $9(9 \times 1)$ and the value of the 2 is 20 ( $2 \times 10)$. This is why 92 is different from 29, although both are combinations of the same digits!

Having the same rules and symbols is great, because it makes it very easy to talk about numbers and calculations. It almost looks like we have one world-wide maths language and that learning basic maths in one country does the job, no need to learn it again in another country. $2+2$ remains 4 , no matter where you are.

\section{LANGUAGES NAME NUMBERS DIFFERENTLY AND THIS CAN MAKE IT EASIER OR MORE DIFFICULT TO LEARN MATHS}

There is just one tiny little problem. Although most of us use the same symbols to write down numbers, we use very different words for these numbers. This is because we speak different languages. In Table 1, you can find examples of number words for the numbers 1-10 in different languages. As you can see, the number words differ a lot between languages-just like most other words also differ between languages. Getting to know the names and the meaning of the numbers 1-10 in your own language is one of the earliest and most important steps in maths learning. However, learning ten number words is equally hard for children speaking different languages. In the end, they all need to learn ten new words; eleven, if we include 0 and 10.

Learning number words for numbers larger than ten differs much more between languages (try the quiz in the Figure 1). In some languages, the way people name multi-digit numbers is very clear and regular. Mandarin (the most popular language in China) is one of these languages. The Mandarin number word for 29 means "two-ten-nine" 


\section{Table 1}

Number words in different languages. Do not worry, you do not have to look at all of them in detail. Maybe focus on the blue ones. All blue number words have something special compared with the very regular Mandarin number words. Below all two-digit number words, you can see how these number words would most likely be translated to English. The way some of these words are built is quite complicated. If you want to know how these number words are pronounced, you can listen to them on the internet. For Mandarin, French, German, and Hindi, go to bing.com/translator and insert the number word. For Basque, have a look at these YouTube videos: https: //www youtube.com/watch? $\mathrm{v}=6 \mathrm{eb} 0 \mathrm{~J} 4 \mathrm{Vg} 5 \mathrm{ys} \&$

feature (numbers

1-19), https: / / www . youtube.com/watch? $\mathrm{v}=\mathrm{wPbYCB} z \mathrm{sw} 2 \mathrm{~A} \&$

feature

(numbers 20-39).

\begin{tabular}{|c|c|c|c|c|c|c|c|}
\hline & Mandarin & English & French & German & Basque & Hindi & \\
\hline 0 & ling & zero & zéro & null & zero, hutsa & shuniye & 0 \\
\hline 1 & yi & one & un & eins & bat & ek & 1 \\
\hline 2 & èr & two & deux & zwei & $\mathrm{bi}$ & do & 2 \\
\hline 3 & sān & three & trois & drei & hiru & teen & 3 \\
\hline 4 & sì & four & quatre & vier & lau & chat & 4 \\
\hline 5 & wŭ & five & cinq & fünf & bost & panch & 5 \\
\hline 6 & liù & $\operatorname{six}$ & $\operatorname{six}$ & sechs & sei & cheh & 6 \\
\hline 7 & qi & seven & sept & sieben & zazpi & saat & 7 \\
\hline 8 & bà & eight & huit & acht & zortzi & aath & 8 \\
\hline 9 & jiǔ & nine & neuf & neun & bederatzi & nao & 9 \\
\hline 10 & shí & ten & dix & zehn & hamar & das & 10 \\
\hline$\overline{11}$ & $\begin{array}{l}\text { shí yi } \\
\text { [ten one] }\end{array}$ & eleven & $\begin{array}{l}\text { onze } \\
\text { [oneteen] }\end{array}$ & $\begin{array}{l}\text { elf } \\
\text { [eleven] }\end{array}$ & $\begin{array}{l}\text { hamaika } \\
\text { [ten one] }\end{array}$ & $\begin{array}{l}\text { gyaarah } \\
\text { [oneteen] }\end{array}$ & 11 \\
\hline 12 & $\begin{array}{l}\text { shí èr } \\
\text { [ten two] }\end{array}$ & twelve & $\begin{array}{l}\text { douze } \\
\text { [twoteen] }\end{array}$ & $\begin{array}{l}\text { zwölf } \\
\text { [twelve] }\end{array}$ & $\begin{array}{l}\text { hamabi } \\
\text { [ten two] }\end{array}$ & $\begin{array}{l}\text { baarah } \\
\text { [twoteen] }\end{array}$ & 12 \\
\hline 13 & $\begin{array}{l}\text { shí sān } \\
\text { [ten three] }\end{array}$ & thirteen & $\begin{array}{l}\text { treize } \\
\text { [thirteen] }\end{array}$ & $\begin{array}{l}\text { dreizehn } \\
\text { [three ten] }\end{array}$ & $\begin{array}{l}\text { hamahiru } \\
\text { [ten three] }\end{array}$ & $\begin{array}{l}\text { tehrah } \\
\text { [thirteen] }\end{array}$ & 13 \\
\hline 16 & $\begin{array}{l}\text { shí liù } \\
\text { [ten six] }\end{array}$ & sixteen & $\begin{array}{l}\text { seize } \\
\text { [sixteen] }\end{array}$ & $\begin{array}{l}\text { sechzehn } \\
\text { [six ten] }\end{array}$ & $\begin{array}{l}\text { hamasei } \\
\text { [ten six] }\end{array}$ & $\begin{array}{l}\text { saulah } \\
\text { [sixteen] }\end{array}$ & 16 \\
\hline 17 & $\begin{array}{l}\text { shí qi } \\
\text { [ten seven] }\end{array}$ & seventeen & $\begin{array}{l}\text { dix-sept } \\
\text { [ten seven] }\end{array}$ & $\begin{array}{l}\text { siebzehn } \\
\text { [seven ten] }\end{array}$ & $\begin{array}{l}\text { hamazazpi } \\
\text { [ten seven] }\end{array}$ & $\begin{array}{l}\text { satrah } \\
\text { [seventeen] }\end{array}$ & 17 \\
\hline 20 & $\begin{array}{l}\text { èr shí } \\
\text { [two ten] }\end{array}$ & twenty & $\begin{array}{l}\text { vingt } \\
\text { [twenty] }\end{array}$ & $\begin{array}{l}\text { zwanzig } \\
\text { [twenty] }\end{array}$ & $\begin{array}{l}\text { hogei } \\
\text { [twenty] }\end{array}$ & $\begin{array}{l}\text { bees } \\
\text { [twenty] }\end{array}$ & 20 \\
\hline 21 & $\begin{array}{l}\text { èr shí yi } \\
\text { [two ten one] }\end{array}$ & twenty-one & $\begin{array}{l}\text { vingt et un } \\
\text { [twenty and one] }\end{array}$ & $\begin{array}{l}\text { einundzwnazig } \\
\text { [one and twenty] }\end{array}$ & $\begin{array}{l}\text { hogeita bat } \\
\text { [twenty and } \\
\text { one] }\end{array}$ & $\begin{array}{l}\text { ikis } \\
\text { [one and } \\
\text { twenty] }\end{array}$ & 21 \\
\hline 29 & $\begin{array}{l}\text { èr shí jiù } \\
\text { [two ten } \\
\text { nine] }\end{array}$ & twenty-nine & $\begin{array}{l}\text { vingt-neuf } \\
\text { [twenty-nine] }\end{array}$ & $\begin{array}{l}\text { neunundzwanzig } \\
\text { [nine and twenty] }\end{array}$ & $\begin{array}{l}\text { hogeita } \\
\text { bederatzi } \\
\text { [twenty and } \\
\text { nine] }\end{array}$ & $\begin{array}{l}\text { Unatis } \\
\text { [one before } \\
\text { thirty] }\end{array}$ & 29 \\
\hline 48 & $\begin{array}{l}\text { sì shí bā } \\
\text { [four ten } \\
\text { eight] }\end{array}$ & forty-eight & $\begin{array}{l}\text { quarante-huit } \\
\text { [forty-eight] }\end{array}$ & $\begin{array}{l}\text { achtundvierzig } \\
\text { [eigth and forty] }\end{array}$ & $\begin{array}{l}\text { borrogeita } \\
\text { zortzi } \\
\text { [forty and } \\
\text { eight] }\end{array}$ & $\begin{array}{l}\text { adtalis } \\
\text { [eigth and } \\
\text { forty] }\end{array}$ & 48 \\
\hline 75 & $\begin{array}{l}\text { qi shí wǔ } \\
\text { [seven ten } \\
\text { five] }\end{array}$ & seventy-five & $\begin{array}{l}\text { soixante-quinze } \\
\text { [sixty-fifteen] }\end{array}$ & $\begin{array}{l}\text { fünfundsiebzig } \\
\text { [five and seventy] }\end{array}$ & $\begin{array}{l}\text { hirurogeita } \\
\text { hamabost } \\
\text { [sixty and ten } \\
\text { five] }\end{array}$ & $\begin{array}{l}\text { chiyahatar } \\
\text { [five and } \\
\text { seventy] }\end{array}$ & 75 \\
\hline 97 & $\begin{array}{l}\text { jiǔ shí qi } \\
\text { [nine ten } \\
\text { seven] }\end{array}$ & ninety-seven & $\begin{array}{l}\text { quatre-vingt } \\
\text {-dix-sept } \\
\text { [four-twenty- } \\
\text { ten-seven] }\end{array}$ & $\begin{array}{l}\text { siebenundneunzig } \\
\text { [seven and ninety] }\end{array}$ & $\begin{array}{l}\text { laurogeita } \\
\text { hamazazpi } \\
\text { [eigthy and } \\
\text { ten seven] }\end{array}$ & $\begin{array}{l}\text { sataanave } \\
\text { [seven and } \\
\text { ninety] }\end{array}$ & 97 \\
\hline 100 & $\begin{array}{l}\text { yì băi } \\
\text { [one } \\
\text { hundred] }\end{array}$ & one hundred & $\begin{array}{l}\text { cent } \\
\text { [hundred] }\end{array}$ & $\begin{array}{l}\text { (ein)hundred } \\
\text { [(one)hundred] }\end{array}$ & $\begin{array}{l}\text { ehun } \\
\text { [hundred] }\end{array}$ & $\begin{array}{l}\text { ek sau } \\
\text { [one } \\
\text { hundred] }\end{array}$ & 100 \\
\hline
\end{tabular}

Table 1

and the number word for 97 means "nine-ten-seven." Scientists call such languages transparent. This means that, in Mandarin, number words fit nicely to the way we write down the digits of multi-digit numbers and the number words clearly show the place-value rule: 97 $=9 \times 10+7=$ "nine-ten-seven."

Scientists found out that learning maths and dealing with multi-digit numbers is easier for children who speak a language with clear number words. However, the problem is that not all languages have clear number words. What do unclear number words look like? Have a look at some of the words for 97. In Basque (a language mostly spoken in a region in the north of Spain), they say "laurogeita 
Figure 1

Which number word on the left belongs to which Hindu-Arabic number on the right? Try to figure it out on your own and then follow the line to check if you were correct. In the article, there are some hints that should help you to figure it out, and Table 1 might also help you make sense of the number words.

\section{TRANSPARENT}

Transparent is another word for clear or well-structured. In the context of number words, the word transparent is used to describe languages in which number words fit nicely to the way we write down the digits of multi-digit numbers. In transparent languages the number words clearly show the place-value rule (e.g., $97=9 \times 10+7$ ="nine-ten-seven").

\section{NUMBER WORD}

\section{INVERSION}

In some languages, the order of numbers in two-digit number words is switched. For example, instead of saying forty-two for the number 42, in some languages they would say two-and-forty. This switching is called number word inversion.

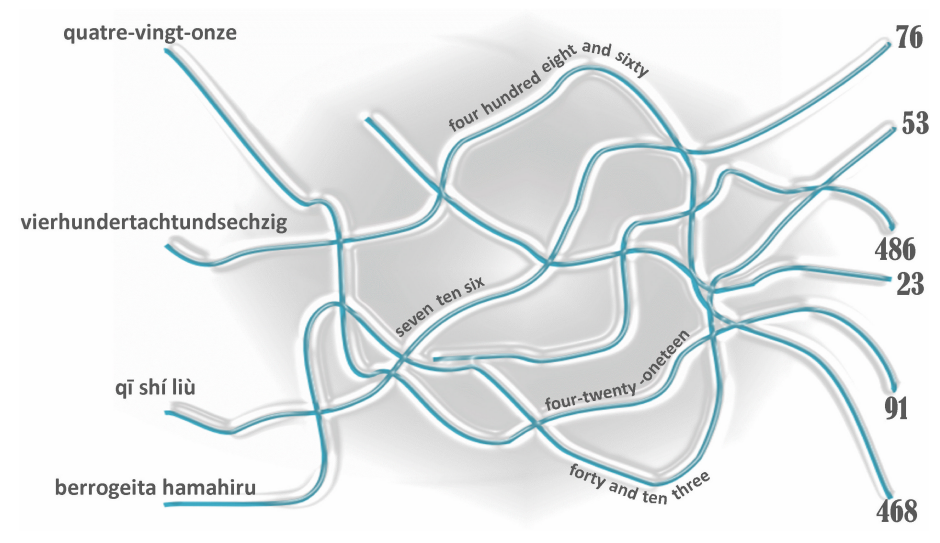

Figure 1

hamazazpi," which means "eighty-ten-seven" $(80+17)$. In French, they say "quatre-vingt-dix-sept," which means "four-twenty-ten-seven" (4 $\times 20+10+7)$. The way these number words are constructed is really complicated. In Hindi (one of the most popular languages in India), there are a few numbers for which people use subtraction rather than addition to build the number word. For example, for the number 29 they say "unatis," which means "one before thirty" (30-1).

In Table 1, you can see the words for some multi-digit numbers in different languages. All the blue number words are somehow unique. The teen numbers are especially difficult to learn in many languages. Wouldn't it be clearer to say "one-ten-two" than "twelve" for 12? Twelve is a new word we need to learn, while for "one-ten-two" we can just use a rule. Saying "fourteen" instead of "teenfour" (or even "one-ten-four," like in Mandarin) is also not that helpful. Why do we sometimes switch the order of numbers and name the units first? Such switching is called number word inversion. In English, only a few teen numbers (thirteen to nineteen) are switched. In other languages, such as German, Dutch, Arabic, or Maltese, all two-digit numbers are switched (97 is "siebenundneunzig" in German, which means "seven-and-ninety"). For larger numbers, it gets even more confusing! The German number word for 234 means "two-hundred-four-and-thirty." Here, the digit on the left is named first, then the digit on the right, and finally the one in the middle. Complicated, isn't it?

It is not surprising that children who speak languages with switched number words have a hard time dealing with multi-digit numbers. German children (switching needed) make more than 5 times as many mistakes when they write down numbers than Japanese children (no switching needed) [1]. About half of the errors German children made involve mixing up the order [2]. For example, when they hear "five-and-forty," they often write down 54 rather than the correct number, 45. So, any child who grows up with a more transparent 
number word system can be happy that they have an easier time learning numbers.

\section{HOWEVER, AFTER SOME TRAINING, MOST PEOPLE JUST LEARN HOW IT IS DONE}

We already know that children speaking a language with non-transparent number words have a harder time with maths compared to children speaking a language with transparent number words. However, most older children and adults usually no longer have such problems. If learning non-transparent number words is only a matter of time or some extra practice, is it really a problem? Well, even though most children quickly deal with it, others keep on struggling. For instance, one study showed that children who struggle with number words at about 7 years old are more likely to have problems with maths 3 years later [3]. So, having problems with number words can show us which children might need some extra help with maths, so that they are not left behind. The earlier we help, the better!

\section{... . BUT THE PROBLEMS START ALL OVER AGAIN WHEN PEOPLE TRY TO DO MATHS IN ANOTHER LANGUAGE!}

More and more people are now traveling and even living in other countries where they need to speak other languages. Sometimes, the new language has a different way of saying multi-digit number words and we must learn these new number words by heart. This can be a big problem, for example, if you come from Poland (no switching needed), and you want to live in Germany (switching needed). Krzysztof, one of the authors of this article, is one of these people. Every single time he does his groceries and tries to pay for them, he gets confused. When the lady at the cash desk says "Neunundzwanzig euro, bitte!" ["Nine-and-twenty euros, please!"], Krzysztof's first thought is "How on earth did I manage to spend almost one hundred euros for food I plan to eat in the next 3 days?" Despite knowing that he must do the switching, and despite doing research on this very topic, it usually takes him a while to calm down and pay the proper amount of money.

Learning number words in a new language is a good start, although this might already be tricky. However, even if you know all the number words in a new language it does not mean that you will want to do maths in this new language. Usually, people prefer to do maths in one language and, in most cases, they do not want to do maths in the language they have just learned to speak. It is more likely that people do maths in their main language, or the language in which they learned to do maths in school. 


\section{CONCLUSIONS}

We use numbers and number words every day and for most of us they are not really special-at least not after some time and practice. However, when we look at number words more closely, it is fascinating to see how languages differ in naming multi-digit numbers. Although number words differ a lot, in most cases the way the number words are built is not random but follows specific rules. Have another look at the quiz in Figure 1. Now that you have learned some of these rules, see if you can decode some of the numbers more easily. Exploring the details of number words can help us understand why children speaking one language might struggle with maths more than children speaking another language. We might also be able to identify children having problems with maths early on and to find out how to support them. Of course, the rules for building number words are not the only thing that is important when learning maths, but it is certainly one piece of the puzzle.

\section{ACKNOWLEDGMENTS}

We thank Ani, age 11, for her comments on an earlier version of the manuscript. We would also like to thank those who assisted in the translation of the articles in this Collection to make them more accessible to kids outside English-speaking countries, and for the Jacobs Foundation for providing the funds necessary to translate the articles. For this article, we would especially like to thank Nienke van Atteveldt and Sabine Peters for the Dutch translation.

\section{REFERENCES}

1. Moeller, K., Zuber, J., Olsen, N., Nuerk, H.-C., and Willmes, K. 2015. Intransparent German number words complicate transcoding-a translingual comparison with Japanese. Front. Psychol. 6:740. doi: 10.3389/fpsyg.2015.00740

2. Zuber, J., Pixner, S., Moeller, K., and Nuerk, H.-C. 2009. On the language-specificity of basic number processing: transcoding in a language with inversion and its relation to working memory capacity. J. Exp. Child Psychol. 102:60-77. doi: 10.1016/j.jecp.2008.04.003

3. Moeller, K., Pixner, S., Zuber, J., Kaufmann, L., and Nuerk, H.-C. 2011. Early place-value understanding as a precursor for later arithmetic performance-a longitudinal study on numerical development. Res. Dev. Disabil. 32:1837-51. doi: 10.1016/j.ridd.2011.03.012

SUBMITTED: 30 September 2019; ACCEPTED: 29 May 2020; PUBLISHED ONLINE: 30 July 2020.

EDITED BY: Stephan E. Vogel, University of Graz, Austria 

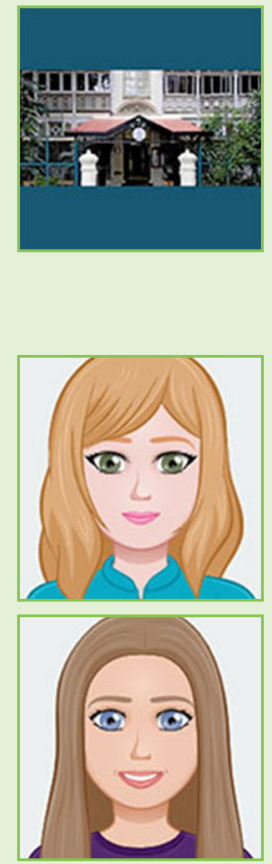

SIENA, AGE: 10

$\mathrm{Hi}$, my name is Siena, I enjoy reading, writing, and cats, and I am in fifth grade.

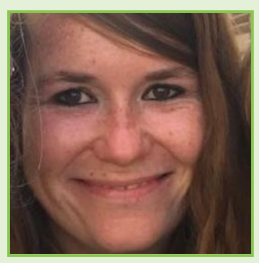

CITATION: Bahnmueller J, Nuerk H-C and Cipora K (2020) Forty-Two or Two-and-Forty: Learning Maths in Different Languages. Front. Young Minds 8:84. doi: 10.3389/frym.2020.00084

CONFLICT OF INTEREST: The authors declare that the research was conducted in the absence of any commercial or financial relationships that could be construed as a potential conflict of interest.

COPYRIGHT @ 2020 Bahnmueller, Nuerk and Cipora. This is an open-access article distributed under the terms of the Creative Commons Attribution License (CC BY). The use, distribution or reproduction in other forums is permitted, provided the original author(s) and the copyright owner(s) are credited and that the original publication in this journal is cited, in accordance with accepted academic practice. No use, distribution or reproduction is permitted which does not comply with these terms.

\section{YOUNG REVIEWERS}

\section{THE BOMBAY INTERNATIONAL SCHOOL, AGES: 13-14}

We are the students of grade 8 at The Bombay International School (two sections of 20 students each) and are interested in the concept of reviewing articles for Frontiers for Young Minds. We enjoy testing our own skills as writers when coming up with feedback for a manuscript. Learning, exploring, and challenging our boundaries is fun. There is so much to learn at Frontiers for Young Minds!

\section{BRIDGET, AGE: 11}

$\mathrm{Hi}$, I am Bridget, I enjoy the exact same things as Siena-learning is fun!

\section{AUTHORS}

\section{JULIA BAHNMUELLER}

In my research, I am interested in how children learn basic maths but also how adults deal with numbers. I am especially interested in how different languages help or sometimes do not help maths learning. I also think it is very important to use the things I learn from research to support children that really struggle with maths, reading, or writing. My main language is German, but I also speak English and French and I am trying hard to learn to speak Spanish right now. *j.bahnmuller@lboro.ac.uk 


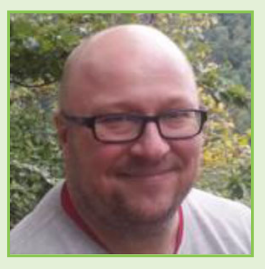

\section{HANS-CHRISTOPH NUERK}

As a child, I was quite late in learning language. I only started talking a bit around 2 years old. On vacation that time, I met a little girl of my age who could already talk. However, I was quite early in learning numbers and calculations. Maybe this is one of the reasons why I am interested in how language influences number processing and maths. Is calculation easier in some languages than in others? Do we need language at all to deal with numbers? Is language especially important when maths problems get more difficult?

\section{KRZYSZTOF CIPORA}

I am a researcher working in Loughborough, UK and I originally come from Poland. I have also lived in Germany for a couple of years. Polish is my main language, and this may be the reason I struggle with German numbers! In my work, I am doing research on how the mind handles numbers and what kind of other information it uses to handle them. Apart from that, I am interested in many things about science in general. In my free time, I love to travel and to hike. My favorite animals are: penguins, giant pandas, alpacas, and koalas. 